\title{
Leipzig 2003
}

\author{
By Ron Holloway \\ Spring 2003 Issue of KINEMA
}

\section{INTERNATIONALES LEIPZIGER FESTIVAL FUER DOKUMENTAR- UND ANIMA- TIONSFILM 2003}

The timing could not have been better. Shortly after the 45th Leipzig International Festival for Documentary and Animation Films (15-20 October 2002) opened with the hit documentary of the year, Michael Moore's Bowling for Columbine (USA), the German edition of Moore's bestselling "Stupid White Men" hit the book stands. The biting, acerbic, stinging Bowling for Columbine had been invited to compete at Cannes and was awarded there an especially created "Unique Prize of the 55th Anniversary Festival." And "Stupid White Men," a riotous political satire penned in the journalistic vein of H.L. Mencken and Mike Royko, rode the best-seller list in the New York Times for nearly a year.

How did this hard-nose statement on gun-related deaths in the United States and the ongoing battle with the gun lobby in Congress get made in the first place? Armed with a disarming smile and a wise-crack for any occasion, Michael Moore hardly looks like a master of the provocative documentary statement. But his subtle gift for the reductio ad absurdum in argumentative give-and-take pays off time and again. Without batting an eye, he lets a bonehead gun-toter casually put his foot in his mouth. He trips gun lobbyists up with their own words. He scolds the media for fostering violence, particularly in the destitute black and Hispanic neighbourhoods. And he chides Charlton Heston for preaching the gospel of the American Rifle Association on the very doorstep of the high school where the Columbine student massacre took place. In short, Moore is squarely on the side of the poor, the unemployed, the downtrodden - even if it means hedging a bet and stretching the truth every now and then. Ever since he took on Roger Smith of General Motors for abandoning his hometown of Flint/ Michigan in Roger and Me (1989) - the film was invited to Leipzig just days after the fall of the Berlin wall - he prides himself on being a self-styled conscience of the nation.

The opening night was also memorable for a stirring address delivered by Andres Veiel, Germany's awardwinning documentary filmmaker (Black Box BRD), at the request of festival director Fred Gehler. Veiel underscored Leipzig's mandate as a leading documentary event. He appraised the revitalized documentary format as a "seismographic instrument" that can effectively analyze the issues and convey the relevant facts to a vexed public. He cited the need for political responsibility in view of the daily threat of an air attack on Iraq. And he praised the DOKfestival "for resisting the impulse of a knee-jerking reaction to current popular themes."

To a great extent, the key films in the Documentary Competition did mirror Andres Veiel's spoken convictions - and they provoked thought and discussion on the social and political issues of the day. The Golden Dove for Best Long Documentary was awarded to Erich Langjahr's Hirtenreise ins dritte Jahrtausend (Shepherds' Journey into the Third Millennium, Switzerland), the third film in his trilogy on "fundamental questions of mankind and human existence" that, taken altogether, form image-wise an ethnographic picturebook on Swiss farming today. Shepherds' Journey into the Third Millennium is best evaluated in conjunction with his earlier Sennen-Ballade (Alpine Ballad) (1996), a poetic ballad on the daily chores of a diary farmer during the summer months, and Bauernkrieg (Peasants' War, 1998), an apocalyptical vision of farming practices threatened by an increasingly mechanized agro-industry. Both of these Langjahr documentaries had competed previously at Leipzig.

Running at two hours in length, Shepherds' Journey into the Third Millennium portrays in minute detail the seasonal chores of two shepherds as they lead their sheep from pasture to pasture, in winter and summer, in fair weather or foul. But as these Swiss shepherds enter the third millennium, they are confronted by sprawling new highways and ever-expanding urban communities. Asked why they have chosen a sacrificial existence even although their own families are anchored in traditional farm life, they respond that shepherding as a philosophy of life satisfies a fundamental longing for freedom. Erich Langjahr's Shepherds' Journey was also awarded the Ecumenical Prize and the Don Quixote Prize of the International Federation of Film Clubs. 
A general theme in this year's competition? Two awarded documentary filmmakers dug into the family past to discover unknown truths about their fathers. In Michael Gaumnitz's Exil in Sedan (Exile in Sedan, France), awarded the FIPRESCI (International Critics) Prize and the Media Trade Union Prize - the director eventually finds out why his father had left Dresden in a hurry shortly after the war to emigrate with his family to the industrial town of Sedan in northeastern France, where ever since the First World War Germans are hardly welcomed, only to return to Germany many years later to spend his last days alone as he drank himself to death. Searching to discover what kind of man his father was, Gaumnitz traces the reasons for his father's affiliation and downfall as a young Nazi recruit, how in the course of the war he had weathered some frightful experiences as an army pen-artist on the front, how he later had to survive by his wits as a black-marketeer in war-torn Dresden, and why he was always just a step ahead of his creditors during his "exile in Sedan." In short, the thin line between perpetrator and victim is effectively rubbed out in this intriguing family document.

The same quest of a son searching to understand his father characterizes Erik Bäfving's Boogie Woogie Daddy (Sweden), awarded the Golden Dove for Best Short Documentary. In his sensitive 13-minute debut film, composed of 3,000 takes, the director portrays a father whose gift for making others laugh with songs and pranks only served to hide a troubled self behind a mask.

Along the same lines on a national level Thomas Heise's Vaterland (Fatherland, Germany), awarded the Silver Dove for Long Documentary, has the director returning to the village community of his youth in eastern Germany, one that had seen better days when the Russians maintained a nearby military airbase and the local pub-keeper could barter for purloined army surplus. Of all the complex documentaries made by Thomas Heise on post-Wende GDR and the downfall of some communities into a social mire and economic wasteland, Fatherland is disturbing for its apocalyptic vision and for posing more questions than attempting any answers at all.

Old-style news-documentaries that challenge the viewer with unsettling facts continue to form the backbone of the DOKfestival. In the sidebar Documentary Program Christian Klemke and Jan N. Lorenzen's Das Ministerium für Staatssicherheit - Alltag einer Behörde (The Ministry of State Security - Everyday Life of a Public Agency, Germany) features frank interviews with nine former generals and top officers of the "Stasi" - when it maintained a staff of 100,000 (!), recruited numerous informers, arrested countless dissidents, and interrogated innocent suspects without the benefit of legal council. "We had a splendid collective in the ministry," recalls deputy director Wolfgang Schwanitz in a moment of unbridled nostalgia for those past glory days.

Similarly, Wilfried Huismann's Des Teufels Lehrling - Mickaels Geschichte (The Devil's Apprentice - Mickael's Story) (Germany), a Competition entry, charts the disturbing fate of a young Belgian-Turk who returns to his homeland to perform his military service, only to end up as an "interrogation specialist" in the service of the Turkish secret police. And Yury Khashchevatsky's Kavkazskie plenniki (A Prisoner in the Caucasus) (Byelorussia/Poland), easily the most disturbing documentary on view in the Competition, questions the wisdom of the ongoing, violent, degrading Russian-Chechnyan conflict by way of citing from a similar "war report" penned by Leo Tolstoy 150 years ago.

For many the DOKfestival is as much animation as it is documentary. Indeed, you had to arrive at some animation screenings early to assure a seat for the Competition Program selected by Otto Adler. Chris Hinton's Flux (Canada), a riotous graphic romp through topsy-turvy family spats, was awarded the Golden Dove for Best Animation. The Silver Doves were shared by Sarah Cox's Plain Pleasures (UK), a subtle mixture of styles and techniques about how social mores can disrupt an evening out between a widow and a bachelor, and Adriaan Lokman's Barcode (Netherlands), a 3D-computerized road movie using abstract graphics to create a virtual world of its own.

By contrast, two delightful 2D-computerized line-animation entries prompted waves of laughter and spontaneous applause from the audience. In Mikhail Aldashin's Bukashky (Little Bugs), awarded the Audience Prize, a community of kitchen bugs construct their own make-shift space ship to escape extermination by alien humans - only to end up splattered on the ceiling. And in Marion Moreau's La mémé et le bébé (Granny and the Baby) (France), an impudent twerp with a milk bottle "raspberries" a toothless grandmother resigned to sucking mashed potatoes through a straw. 
And not enough can be said for the festival's salute to three masters of European animation. For the "Tribute to Jan Lenica" (1928-2001) devotees were treated to a sparkling refresher course in Marcin Gizychi's The Island of Jan Lenica" (Poland, 1998). For the "Marvelous World of Jury Norstein" five of the Russian artist's outstanding films of the 1970s were assembled in an honorary program. And for the "Jerzy Kocia Homage" the festival presented six of the Polish animator's patented absurd and experimental films that had been awarded over the past thirty years.

On any given day, to the delight of many and the chagrin of others, the festival visitor is obliged to choose from a broad lineup of sidebar entries in the Documentary Program, the Retrospectives, the Special Events, and the Workshops. In the "Programm DOK" you could see, for instance, Jouni Hokkanen and Simojukka Ruippo's Pyongyang Robogirl (Finland), a delightful sketch of the antics practised by a young woman traffic cop at a busy intersection in the North Korean capital of Pyongyang.

Also, Yevgeny Solomin's Katorga (Russia), produced by Kino-Siberia in Novosibirsk, features an interview with a repentant young prisoner at the brutal Siberian State Penitentiary ("Katorga") as he is about to face a commission that will decide upon his early release. And Martina Döcker's nostalgic Peymanns Stuttgarter Kinder (Peymann's Stuttgart Children, (Germany) traces the explosive years of drama director Claus Peymann at the Staatstheater Stuttgart from 1974 to 1979. The quaint, sometimes confessional, recollections of five faithful fans are further augmented by Peymann's own statements about the local political scene, for his tenure as drama director just happen to coincide with the tragic Baader-Meinhof trial at the nearby Stammheim prison.

The "Frauen - Film - Frauen" Retrospective, assembled by the German Federal Film Archive, presented in documentary and animation an all-embracing portrait of "Women in Film" from the pioneer silents of the Weimar Republic to the immediate postwar cinema (up to 1954) of East and West Germanys. The retro opened appropriately with Heide Breitel's Die kleinen Kleberinnen (The Petite Film Splicers) (FRG, 1980), her lauded student documentary made at the Berlin Film Academy.

On the next day, Breitel's latest documentary, Ich kann das schon (I Can Already Do That) - the title refers to a girl afflicted by Downs Syndrome who delights in her mastery of tasks placed before her - proved to be such a hit in the Documentary Program that one wonders why it had not been selected for the Competition. Breitel chronicles the courage, as well as misgivings, of three sets of parents who have to deal with the challenge of retarded children in their daily lives. An honest and sincere film.

"Pavel und Ljalja," a series highlighted in the Documentary Program, offered historians the opportunity to review the best Russian films directed by Pavel Kogan and his wife Lyudmila ("Lyalya") Stanukinas. For some thirty years the couple had been documenting events from everyday life and the arts scene in Leningrad (St. Petersburg). Another series, "10 Years of ARTE," the DOKfest's anniversary tribute to a faithful sponsor, charted how this popular German-French cultural channel soon became a welcomed haven for the world-wide documentary film. "Sertschawan - Willkommen bei meinen Augen" (Sertshavan - Welcome in My Eyes), a program of 21 films documenting the plight of Kurds living in Iraq, Iran, and Turkey, was particularly relevant in view of the imminent possibility of an air strike on Baghdad. And "Der zerbrochene Spiegel" (The Broken Mirror) focused on the "Jewish search for identity" in a series of documentary films from Central and Eastern Europe.

The Leipzig DOKfestival can take justified pride in a grand tradition. No other festival to my knowledge so effectively links Retrospective Tributes and Special Events to complementary Workshops. Take, for example, the presence of GDR documentary veteran Karl Gass, who mesmerized a crowd at the Polish Cultural Institute (PCI) with a Workshop on "Das Jahr 1" (The First Year), and this following a screening of the very films that had been featured at the 1. Leipziger Kultur- und Dokumentar-filmwoche back in September of 1955. Not many were aware that this First Leipzig Cultural and Documentary Film Week had been initially conceived as a friendly exchange between the GDR and the FRG at a kind of German-German arts scene. "Needless to say," observed Karl Gass, "the mood at this first Leipzig festival was euphoric - something that could not be said about 'Year 2' in 1956, when officials voiced their criticism and halted the experiment on the spot!" Leipzig then had to wait until 1960 for a festival comeback - this time as an international documentary event that has carried up to the present. 
Another vital PCI Workshop, titled "Das Porträt des Deutschen im polnischen Dokumentarfilm - Das Porträt des Polen im deutschen Dokumentarfilm," co-chaired by critic-historians Christiane Mückenberger (Germany) and Maria Malatynska (Poland), scrutinized how neighbouring countries depicted people living on the other side in their respective documentary films. And a third Workshop reviewed a collection of awarded "Student Films of the Lodz Film School."

The 45th DOKfilmfest Leipzig drew its highest attendance since 1989. Altogether, an audience of 20,500 saw 369 films. Viewed from this angle, Leipzig is Germany's fastest growing film festival and Europe's premier venue for the documentary film. The 224-page festival catalogue is a collector's item in itself.

\section{References}

\section{AWARDS}

Golden Dove, Long Documentary

Hirtenreise ins dritte Jahrtausend (Shepherds' Journey into the Third Millennium, Switzerland), Erich Langjahr

Silver Dove, Long Documentary

Vaterland (Fatherland, Germany), Thomas Heise

Golden Dove, Short Documentary

Boogie Woogie Daddy (Sweden), Erik Bäfving

Silver Dove, Short Documentary

Porträt (Portrait) (Russia), Sergei Loznitsa

Golden Dove, Animation

Flux (Canada), Chris Hinton

Silver Doves, Animation

Plain Pleasures (UK), Sarah Cox

Barcode (Netherlands), Adriaan Lokman

Prize for Best Camera

Sophie Maintigneux, Damen und Herren ab 65 (Ladies and Gentlemen over 65, Germany), directed by Lilo Mangelsdorff

MDR (Mitteldeutscher Rundfunk) Film Prize

Brot über den Zaun (Bread over the Fence, Bulgaria), Stephan Komandarev

FIPRESCI (International Critics) Prize

Exil in Sedan (Exile in Sedan, France), Michael Gaumnitz

Ecumenical Jury

Hirtenreise ins dritte Jahrtausend (Shepherds' Journey into the Third Millennium) (Switzerland), Erich Langjahr

Don Quixote Prize - FICC (International Federation of Cine Clubs)

Hirtenreise ins dritte Jahrtausend (Shepherds' Journey into the Third Millennium, Switzerland), Erich Langjahr

ver.di (Media Trade Union) Prize

Exil in Sedan (Exile in Sedan, France), Michael Gaumnitz

Leipzig Youth Jury Prize

Boogie Woogie Daddy (Sweden), Erik Bäfving

Mephisto-97.6 Audience Prize

Bukashky (Little Bugs, Rssia), Mikhail Aldashin 


\section{Author Information}

Ron HOLLOWAY (1933-2009) was an American critic, film historian, filmmaker and correspondent who adopted Europe as his home in the early fifties and spent much of his life in Berlin. He was an expert on the study of German cinema and against all odds produced, with his wife Dorothea, the journal German Film, keeping us up-to-date with the work of directors, producers and writers and the showing of German films around the world.

In 2007, Ron Holloway and his wife were awarded the Berlinale Camera Award. Ron also received the Bundesverdienstkreuz (German Cross of Merit), Polish Rings, Cannes Gold Medaille, the American Cinema Foundation Award, the Diploma for Support of Russian Cinema and an honorary award from the German Film Critics' Association.

Ron was also a valued contributor to Kinema for the past fifteen years. 